TEME, г. XLII, бр. 3, јул - септембар 2018, стр. 801-820

Прегледни рад

DOI: $10.22190 /$ TEME1803801D

Примљено: 1. 2. 2017.

UDK 809.199:802.0

Ревидирана верзија: 1. 5. 2018.

615.811

Одобрено за штампу: 12. 6. 2018.

\title{
УЛОГА ДЕРИВАЦИЈЕ У НАСТАВИ ВОКАБУЛАРА ЕНГЛЕСКОГ ЈЕЗИКА ${ }^{a}$
}

\section{Јелена Даниловић Јеремић}

Универзитет у Крагујевцу, Филолошко-уметнички факултет, Крагујевац, Србија

jelena.jeremic@filum.kg.ac.rs

\begin{abstract}
Апстракт
Историјски посматрано, морфологија је дуго остајала на маргини примењенолингвистичких истраживања, запостављена у наставним плановима и водећим научним часописима. Последњих двадесет година ситуација се, међутим, значајно променила, па је данас морфологија у жижи интересовања како лингвиста тако и наставника, који настоје да, из неколико углова, испитају усвајање разних морфолошких процеса код деце, одраслих и ученика различитих нивоа знања. У складу са поменутим тенденцијама, циљ нашег рада је да представи нераскидиву повезаност морфологије, прецизније деривације, и вокабулара, као и начине представљања грађе и типове вежбања који доприносе језичком освешћивању, а све то у контексту усвајања (деривационе морфологије) енглеског као страног језика. Освртом на релевантну литературу и анализом наставних материјала посвећених деривацији покушаћемо да скренемо пажњу на значај морфологије у процесу учења и усвајања енглеског језика, што до сада у домаћим наставним оквирима није истицано.
\end{abstract}

Кључне речи: деривација, вокабулар, афикси, настава, енглески као страни језик.

\footnotetext{
${ }^{a}$ Рад је настао у оквиру пројекта 178014: Динамика структура савременог српског језика, који финансира Министарство просвете, науке и технолошког развоја Републике Србије.
} 


\title{
TEACHING ENGLISH VOCABULARY: THE ROLE OF DERIVATION
}

\begin{abstract}
Historically speaking, morphology had long figured as a marginal area of applied linguistic research. Its absence was particularly noticeable in teaching curricula and leading scientific journals. The last twenty years have seen a significant change, and morphology is nowadays gaining considerable attention as linguists and teaching practitioners alike are attempting to explore, from various standpoints, the acquisition of morphological processes in children, adults and L2 learners of differing proficiency levels. In line with these tendencies, the aim of this paper is to shed light on the immanent interrelatedness of morphology, specifically derivation, and vocabulary, and present EFL teaching and learning practices which contribute to an improved awareness of English derivational morphology. By drawing on the relevant literature and analyzing teaching materials that focus on derivation, we will try to draw attention to the importance of morphology in the process of English language learning and acquisition, an issue that has hitherto been underemphasized in the Serbian EFL context.
\end{abstract}

Key words: derivation, vocabulary, affixes, teaching, EFL.

\section{УВОД}

У англистичкој литератури, морфологија се превасходно дефинише као дисциплина која проучава флексију и творбу речи (енгл. word-formation). Творба речи се затим даље може поделити на деривацију и композицију (Bauer, 1983; Plag, 2003). Флексија, тј. флективна афиксација, јесте граматички процес у коме учествују само суфикси - они су носиоци граматичких информација као што су лице, број, аспект или време и у енглеском језику су малобројни: постоји свега осам суфикса којима се обележавају присвојни облици, множина именица, садашње и прошло време, партиципи, компаратив и суперлатив. Насупрот релативно слабо развијеној флективној морфологији, налази се, међутим, богат деривациони систем који обилује како префиксима тако и суфиксима.

Поред конверзије и композиције, деривација представља један од три најпродуктивнија начина творбе речи у савременом енглеском језику. Како наводе Пајлз и Алџео (Pyles \& Algeo, 1993, стр. 285), на основу података прикупљених у периоду 1941-1991. године, композицијом је, током тих година, настало $40 \%$ нових лексема, деривацијом $28 \%$, а конверзијом $17 \%$. За настанак преосталих $15 \%$ нових речи одговорни су тзв. споредни творбени процеси, тј. повратно извођење, сливање, удвајање или скраћивање.

Имајући у виду да је деривација један од два кључна лексичка процеса којима се богати речник енглеског језика, можемо претпоставити да је њена улога у усвајању лексичког знања веома важна. Морфолошка и психолингвистичка истраживања показала су да из- 
ворни говорници енглеског језика, управо захваљујући познавању деривационих афикса, могу да разумеју лексеме са којима се никада раније нису сусрели, али и да буду креативни и сами стварају језичке новитете. ${ }^{1}$ Функционисање и значај познавања деривационе морфологије можемо илустровати примерима које је Џорџ В. Буш, 43. председник Сједињених Америчких Држава, сковао спонтано, током усмених обраћања (Harley, 2006, стр. 112-113):

The war on terrorism has transformationed [transformed] the USRussia relationship.

This case has had full analyzation [analysis] and has been looked a lot. equipment...

Thirdly, the explorationists [explorers] are willing to only move

Сваки од неологизама које је бивши председник САД-а употребио сведочи о његовом интуитивном познавању правила комбиновања морфема и творбе речи. Његове кованице, иако непознате широј јавности, код ње не би наишле на неразумевање јер би познавање значења афикса и творбених основа (transform + -ation $+-e d$, analyze + -ation, explore + -ation $+-i s t+-s)$ и примена принципа аналогије омогућила изворним говорницима да схвате шта је тадашњи први човек државе намеравао да каже.

За разлику од изворних говорника код којих се свест о морфолошким односима развија несвесно, од најранијих ступњева језичке употребе, па све до тинејџерског доба (Nagy, Diakidoy \& Anderson, 1993), ако не и касније, ученицима енглеског језика као страног $^{2}$ који језик усвајају у формалним наставним условима, уз много мање језичког инпута, неретко је потребна помоћ при развијању овог вида граматичке компетенције.

\section{УСВАЈАҢЕ ВОКАБУЛАРА ЕНГЛЕСКОГ ЈЕЗИКА: СТРУКТУРА И ВЕЛИЧИНА ФОНДА РЕЧИ}

Улога вокабулара у настави мењала се током година под утицајем релевантних теоријских и методолошких поставки. Већи део прошлог века остајала је на маргинама будући да је централно место у наставним програмима и инструкцијама заузимала граматика. Међутим, у другој половини 20. века долази до заокрета у поимању ме-

\footnotetext{
${ }^{1} \mathrm{O}$ продуктивности појединих афикса у савременом енглеском језику в. код Адамс (Adams, 2013).

2 У овом раду неће се инсистирати на, методички оправданој, разлици између процеса усвајања енглеског као другог и страног језика, већ ће се, за оба контекста, користити скраћеница J2.

${ }^{3}$ Граматичка компетенција, као један од аспеката комуникативне компетенције, укључује познавање лексичких јединица и правила морфологије, синтаксе, реченичне семантике и фонологије (Richards \& Rogers, 2001).
} 
ста вокабулара у настави, нарочито под утицајем комуникативног метода. Увиђа се да се без адекватног фонда речи, упркос познавању граматичких структура и функција, не може успешно комуницирати.

О задатку који чека ученике енглеског као J2, у смислу броја речи које је потребно савладати, њихове тежине, као и самом значају величине лексичког фонда, не може се говорити а да се не помене, етимолошки гледано, природа енглеског језика. Могло би се рећи да је она, у суштини, двојака. С једне стране, многе речи су германског (тј. англосаксонског) порекла и оне чине најфреквентнији слој лексике; како наводи Берд (Bird, 1987), међу 100 најфреквентнијих речи у енглеском, $97 \%$ је германског порекла. Оне обухватају чланове, заменице, везнике, помоћне глаголе и многобројне денотате свакодневних предмета и идеја, као што су house, daughter, door, horse, head, ship, love или water. Као што видимо, те лексеме су већином кратке, једносложне или двосложне. Такође, оне се ретко комбинују са префиксима и суфиксима. Други доминантан слој лексике у енглеском потиче из француског, односно латинског, јер су различите историјске и друштвене околности довеле до обилног позајмљивања речи. Иако је међу првих 100 најфреквентнијих речи само 3\% латинског порекла, овај проценат се прогресивно увећава: међу првих најфреквентнијих 1000 их је 36\%, у наредних 1000 51\% итд. (Ибид.). Те речи су махом вишесложне, садрже префиксе и суфиксе, могу да улазе у нове деривационе комбинације, а неретко су и маркери формалног стила - за поједине концепте постоје синонимне лексеме англосаксонског порекла (уп. receive-get, purchase-buy, fatigue-weariness, nauseous-sick, jubilant-happy). Формални аспект употребе поменутих лексема лако се уочава у листи речи које се учестало користе у академском дискурсу, тзв. Academic Word List (Coxhead, 1998, 2000): она садржи чак $90 \%$ речи чије се порекло може довести у везу са француским, латинским и грчким утицајем.

Грчко-латински карактер дела лексикона, нарочито у домену академске лексике, отежава усвајање енглеског језика не само ученицима енглеског као J2 већ и изворним говорницима. Корсон (Corson, 1985, 1995, 1997) сматра да ове речи заправо представљају својеврстан лексички степеник (енгл. lexical bar); наиме, да би успели у академском свету, говорници морају да превазиђу ову „препреку”, то јест, да савладају грчко-латинске речи, и то не само рецептивно већ и продуктивно. Проблем је у томе што су те лексеме обично дуге, састављене од основе и префикса и/или суфикса, па је потребно више времена за њихово процесуирање (нпр. practitioner, intermediate, qualitative, preliminary). Такође, потребан је значајан инпут, у виду интензивног читања литературе богате формалном лексиком, како би се те речи прво учестало сретале, а потом и усвојиле. Не долазе сви студенти, наиме, из друштвеног миљеа у коме су окружени овим мање фреквентним јединицама вокабулара. 
Штавише, за неке од њих оне заувек остају у сфери рецептивног, а не продуктивног знања.

Специфичност порекла лексике у енглеском језику огледа се у „високофреквентним” (енгл. high-frequency words) и „нискофреквентним" речима (енгл. low-frequency words) које су до сада, на основу обимних корпуса, на различите начине пописиване и сврставане у листе (уп. Thorndike \& Lorge, 1944; West, 1953; Kucera \& Francis, 1967). У већини њих дата реч заправо представља само једног члана породице речи (енгл. headword), при чему се подразумева да она обухвата и све остале деривационе и флективне облике који се из ње могу извести, а који се не броје и не појављују као засебне одреднице (нпр. excite обухвата и excitement, exciter, exciting, excited итд.). Управо ове листе омогућавају наставницима да одлуче које су речи најкорисније за ученике, односно којим речима треба посветити пажњу у учионици. Готово сви аутори који су се бавили усвајањем вокабулара сагласни су да је врло важно да ученици J2 усвоје првих 2000 најфреквентнијих речи, па стога за њих треба одвојити време у настави. Тај број ће ученицима омогућити да разумеју око $80 \%$ речи које се појављују у различитим врстама текстова (Nation, 2001).

Да би могли да читају аутентичне текстове на енглеском, ученици морају да знају најмање од 3000 до 5000 речи (Nation \& Waring, 1997). Управо зато се у настави користе материјали прилагођени различитим нивоима лексичког знања, од почетног до напредног, који поред уџбеника и радних свески обухватају и лектиру (енгл. graded readers). Виши нивои знања, од 5000 до 6000 речи, омогућавају разумевање готово 90\% текстова, док се уз величину вокабулара између 15.000 и 16.000 јединица може разумети 97,8\% текстова (Ибид., стр. 9).

На основу односа између величине лексичког фонда и способности разумевања текста, види се да што је фонд већи - утолико је разумевање боље. Будући да се значајан раст вокабулара, од око 2500 речи годишње, код неизворних говорника по правилу дешава у условима када се они нађу у говорној средини J2 (Singleton, 1989; Milton \& Meara, 1995), наставу вокабулара у учионици треба подредити потребама ученика. Уколико средњошколци планирају да наставе своје школовање, њима би, поред првих 2000 најфреквентнијих речи, могло бити од користи 570 речи које се јављају у AcademicWordList (Coxhead, 1998). Другим речима, сматра се да након нивоа од 2000 речи, наставу вокабулара треба специјализовати јер поред високо и нискофреквентних речи, вокабулар обухвата како лексику ужих научних области (енгл. technical vocabulary) тако и лексику карактеристичну за сва академска поља (енгл. academic vocabulary). Општа је препорука да на многобројне нискофреквентне речи, будући да оне обично захватају веома мали део било ког текста на енглеском, не треба трошити време у учионици - уместо тога, препоручује се да наставници помогну ученицима у развијању стратегија које би им омогућиле да самостално допру 
до значења тих речи (нпр., ослањајући се на контекст, користећи речник или примењујући стечена знања о морфолошким сегментима). Из овога произлази да морфологија заслужује место у настави енглеског као J2 она може да олакша разумевање речи и њихово памћење, али и да прошири опсег ученикових средстава изражавања.

Ваља напоменути да је данас распрострањено уверење да је величина вокабулара млађе популације одраслих говорника енглеског као J1 између 15.000 и 20.000 речи (Nagy \& Anderson, 1984; Nation \& Waring, 1997). То значи да су они, од најранијег узраста, у просеку усвајали око 1000 или 2000 речи годишње. Ситуација је, свакако, много другачија у контексту институционалног усвајања енглеског као J2. Истраживања Хелен Барнард (Barnard, 1961) и Џорџа Квина (Quinn, 1968) указала су да ученици у Индији и Индонезији, након пет година интензивног учења језика у учионици, располажу фондом од 1000 до 2000 речи. Нешто новије студије потврдиле су њихове налазе и у другим наставним контекстима. Кармен Олмос (Olmos, 2009), примера ради, испитивала је величину вокабулара код средњошколаца у Шпанији. Иако су ови ученици, према прописаном државном курикулуму, провели осам година учећи енглески, пред крај другог циклуса образовања знали су свега 10002000 речи.

На основу свега наведеног, можемо закључити да је процес усвајања лексичког знања J2, чак и када се узму у обзир најоптимистичније прогнозе и резултати, дуготрајан и спор. У формалним наставним условима неопходан је дуги низ година да неизворни говорници усвоје више од 2000 основних речи енглеског језика, а и тај минимални лексички фонд који омогућава читање текстова без већих потешкоћа за многе остаје недостижан циљ. Али, треба имати у виду да постоје значајне разлике између рецептивног и продуктивног знања лексике, о чему ћемо нешто више рећи у наредним редовима.

\section{ЛЕКСИЧКО ЗНАЫЕ И МОРФОЛОШКА СТРУКТУРА РЕЧИ}

Бројни лингвисти покушали су да дефинишу шта све обухвата познавање неке речи. Нејшн (Nation, 2001, стр. 35) сматра да би се, у најужем смислу, могло говорити о три аспекта: форми, значењу и употреби. Са овим је сагласна и Шанел (Chanell, 1988), која тврди да је реч усвојена када је ученик у стању да препозна њено значење, и у контексту и изван њега, и да је на природан и прикладан начин употреби. Међутим, како каже Нејшн (Nation, 2001, стр. 23):

„речи нису изоловане језичке јединице, већ се уклапају у многе међусобно испреплетане системе и нивое. Због тога постоји доста тога што о свакој датој речи треба знати, као што постоји и много степена једног таквог познавања". 
Знање речи огледа се и у познавању синтагматских и парадигматских односа у које реч улази, контекста у коме се јавља, као и њених синтаксичких, семантичких и прагматичких одлика. Такође, ваља истаћи да разумевање неке речи није исто што и њена продукција.

Ово нас доводи до терминолошке дистинкције која се обично прави када се говори о учењу вокабулара: постоји рецептивно и продуктивно знање лексике. Ове две врсте знања често се доводе у везу са рецептивним (слушање и читање) и продуктивним (говор и писање) језичким вештинама. Поједностављено гледано, рецептивно знање обухвата способност да се реч препозна и њено значење призове; продуктивно знање укључује све то, али и способност да се реч изговори или напише у прикладној ситуацији.

Нејшн је (Nation, 2001, стр. 27) детаљно разрадио све аспекте познавања речи - рецептивног и продуктивног - имајући у виду тројство форме, значења и употребе. Рецептивна димензија лексичког знања укључује препознавање делова речи (тј. морфема), али и њиховог значења. Продуктивна димензија укључује способност да се нека реч конструише помоћу одговарајућих елемената, односно њихових облика. Сасвим је јасно да ученици енглеског као J2 у оба случаја морају да поседују свест о деловима речи (енгл. morphological awareness) како би се могло рећи да неку реч знају, било рецептивно, било продуктивно.

Морфолошко знање, дефинисано као аспект познавања структуре речи, у овом погледу помиње и Лауфер (Laufer, 1997: 141). По њеном мишљењу, оно обухвата познавање основне слободне или везане коренске морфеме, као и уобичајене деривационе и флективне облике који се од неке речи могу извести.

На ово се надовезују Шмит и Макарти (Schmitt \& McCarthy, 1997: 2) запажањем да је један од најутицајнијих чинилаца у усвајању вокабулара J2 који одређује да ли ће ученици речи перципирати као „лаке” или „тешке” (енгл. learning burden) - њихов J1. Наиме, што су језици сличнији (тј. ако међу њима постоји знатно концептуално поклапање јединица), већа је вероватноћа да ће се мапирање нове речи $\mathrm{J} 2$, заправо, сводити на додавање нове етикете речи која постоји у J1. Међутим, уколико се језици у великој мери разликују, некада је неопходно усвојити читаве системе, као што су друго писмо, гласови и комбинације гласова, или синтаксичке категорије попут чланова и наставака за падеже, што све отежава процес усвајања J2.

Утицај матерњег језика може се сместити у шири оквир који одређује количину напора који треба уложити да би се нека реч J2 научила. Што је реч повезанија са другим обрасцима које ученик већ познаје, било из матерњег језика, других страних језика или дотадашњег искуства у учењу J2, утолико ће оптерећење бити мање. Наставници могу да допринесу умањењу оптерећења тако што ће 
пажњу ученика усмерити ка обрасцима страног језика и указати на аналогије које се могу извести, али и истицањем сличности између матерњег и страног језика (Nation, 1990).

У поменуте обрасце и аналогије неминовно спада и морфолошка компетенција. Будући да су многе енглеске речи изведене додавањем афикса другим речима (нпр., unprofitable), уколико ученици познају значења афикса (un-, -able), то ће смањити оптерећење при учењу нових речи које их садрже. Развијање способности да се реч растави на морфеме омогућава ученицима не само препознавање значења нових речи већ и њихову потоњу продукцију (Laufer, 1997, стр. 146). Захваљујући заједничком пореклу или језичким позајмљеницама, многи језици имају у свом саставу сличне лексеме које олакшавају учење лексике J2 (нпр., у случају француског и енглеског језика, постоје парови попут table-table, charité-charity, mariage-marriage). Овај потенцијал би свакако требало искористити у учионици, нпр., састављањем листа сродних речи. У случају енглеског и српског језика, таква листа могла би да садржи парове попут professionalismпрофесионализам, performance-nерформанс, таnagement-менаимент, leader-лидеp, shopping-шопинг, yoghurt-jozypm. Поједине речи у српском, штавише, садрже афиксе који се, у истом или нешто измењеном ортографском облику, појављују у енглеском (нпр., -итет/ity, -изам/-ism, -ucm/-ist, -озан/-ous, -ep/er, -aunja/-ation). ${ }^{4}$ Ученици који не препознају порекло таквих речи, међутим, можда ни не увиђају лексичке и морфолошке сличности које постоје између енглеског и српског. ${ }^{5}$ У време глобалне доминације енглеског, можемо очекивати да ће се прилив нових речи наставити, па би упознавање ученика са овим трендом, те сродним речима и афиксима - свакако унапредило њихову аутономију у учењу енглеског: могли би самостално да трагају за сличним лексемама и тако унапређују своје лексичко знање.

\section{РАЗВОЈНИ ТОК УСВАЈАҢА РЕЧИ И ПОЗНАВАҢЕ ДЕРИВАЦИЈЕ}

Усвајање вокабулара је сложен и вишестран процес који се, како наводе Морган и Ринволукри (Morgan \& Rinvolucri, 2004, стр. 7), не одвија линеарно, већ се грана. Како они објашњавају, речи се не уче механички, као некакви пакети знања, него се усвајају путем

\footnotetext{
${ }^{4}$ Више о утицају сродних афикса на познавање деривације код ученика енглеског којима је матерњи језик српски видети код Даниловић, Димитријевић Савић и Димитријевић (2013) и Димитријевић Савић и Даниловић (2011).

${ }^{5}$ Отвиновска-Каштеланик (Otwinowska-Kasztelanic, 2010) код пољских ученика енглеског (чије је знање J2 било на напредном нивоу) запазила је недостатак свести о постојању сродних, пољско-енглеских парова лексема управо због перципиране типолошке удаљености два језика.
} 
асоцијација. Овај процес је крајње субјективан, јер асоцијације које ученици праве зависе од њихових прошлих и садашњих искустава. Истовремено, то је и друштвени процес, пошто се разумевање значења речи обогаћује у размени са другим људима. Напослетку, усвајање вокабулара није искључиво интелектуални процес у који ваља уложити много времена и труда, већ и својеврстан искуствени процес - уколико му се исувише интелектуално приступа, језик he се пре посматрати као објекат, него као нешто што треба да, у извесном смислу, постане део самог ученика (Ибид.).

Природа усвајања вокабулара је, уједно, кумулативна (Schmitt, 2000): у почетку, ученици уче основно значење речи, њен изговор и писање да би се, потом, веза између значења и форме постепено обогаћивала и јачала. Све ово доводи се у везу са квалитетом менталног процесуирања, тј. врстом пажње која се усмерава на лексичке јединице. Ова идеја потиче из области когнитивне психологије (енгл. The Depth of Processing Hypothesis); наиме, истраживачи су установили да активности које захтевају дубљу обраду информација доводе до успешнијег учења (Craik \& Lockhart, 1972). Када ученици виде неку реч и дефиницију њеног значења, не улажу напор да се сами присете значења, што одмаже учењу. Много је делотворније пред ученике поставити изазов и активирати њихове менталне процесе, па им тек накнадно пружити повратну информацију о значењу циљне речи или ће бити потребно много понављања да би реч остала дугорочно запамћена. Неопходно је, дакле, да ученици активно учествују у процесу усвајања лексике, а наставникова улога у учионици понајвише се огледа у осмишљавању начина на које ће држати њихову пажњу, али их и охрабрити да се максимално ангажују, труде и активирају постојећа знања.

С обзиром на то да познавање речи укључује бројне аспекте, очигледно је да наставници не могу сами да, циљаним и систематским деловањем, допринесу усвајању вокабулара код ученика; потребно је да ученике обуче за самосталан рад, уз примену разноврсних стратегија као што су стратегија памћења или разне социјалне, когнитивне, метакогнитивне, афективне и компензационе стратегије (в. Oxford, 1990). Оне ће ученицима омогућити да контролишу и унапреде своје учење и употребу језика у комуникативне сврхе. Најуспешнији ученици су обично управо они који се ослањају на широк дијапазон стратегија за учење вокабулара (Read, 2000). Једна од тих стратегија јесте и анализа делова речи, односно ослањање на значење афикса и корена речи (нпр., познавање значења префикса $e x$ - ‘бивши' омогућава ученику да протумачи значење деривата ex-president као 'бивши председник'). Познавање ових компоненти вишеструко је корисно: оне омогућавају увиђање веза између морфолошки повезаних речи, проверавање претпоставки о значењу речи на основу контекста, јачање веза 
између облика речи и њеног значења, као и разумевање самог значења нових речи. Примена знања из области морфологије спада у стратегије које олакшавају откривање значења речи, али и оне које омогућавају њено консолидовање (Schmitt, 1997, стр. 207-208).

Поред препознавања морфема, у учионици се препоручује и настава посвећена значењу афикса и правилима њиховог комбиновања са основама, која ће код ученика унапредити рецептивно и продуктивно знање речи. Како каже О’Дел (O’Dell, 1997, стр. 277),

„ученик који зна реч translate сигурно може разумети, а вероватно и произвести, речи попут mistranslate, re-translate, untranslatable, translator, co-translator, translation и mistranslation".

Сличног је мишљења и Шмит (Schmitt, 1997, стр. 226). Он истиче да актуелни комуникативни приступ настави страних језика ставља акценат на смислене, интерактивне активности у учионици, запостављајући форму речи. То би требало променити, будући да употреба афикса, као једна од стратегија дубљег процесуирања, свакако завређује пажњу ученика.

\section{ДЕРИВАЦИЈА У УЧИОНИЦИ: НАСТАВНИ МАТЕРИЈАЛИ И ТЕСТОВИ}

Истраживачи који су се бавили развитком лексичког знања код изворних говорника енглеског сагласни су, у начелу, да у овом процесу кључну улогу играју три чиниоца. Лексика се може усвојити на следеће начине: (1) подучавањем и свесним учењем нових речи, (2) сретањем нових речи у контексту и (3) препознавањем и грађењем нових речи помоћу префикса, суфикса и других творбених средстава (Nation, 2001, стр. 263). Значај познавања морфологије учестало се помиње и у контексту усвајања енглеског као J2, о чему сведоче бројни наставни материјали који садрже вежбе, игре и практичне савете о употреби и значењу појединих афикса, а све у циљу промовисања и унапређивања језичке свести ученика.

Да би могли да примене знања која се тичу делова речи, ученици морају да буду у стању да их препознају, да познају значења најфреквентнијих афикса, као и да разумеју како је значење афикса повезано са значењем читаве речи. У ту сврху, у књизи New Ways in Teaching Vocabulary (Nation, 1994), под насловом Wordbuilding (срп. творба речи), појављује се неколико активности које се могу применити у учионици. Оне су осмишљене да кроз рад у пару или групи развију знање ученика о префиксима, суфиксима, члановима породице речи (енгл. word family) и творбеним процесима у енглеском. Тако се, на пример, ученицима могу дати чланци из новина у којима треба да пронађу све префиксе и суфиксе, а затим да те афиксе групишу у четири колоне у зависности од тога да ли се појављују у именицама, глаголима, при- 
девима или прилозима (активност: Find the Prefixes and Suffixes; Ибид., стр. 190). Ми бисмо додали да се слична активност може организовати са ученицима различитих нивоа знања тако што би се од њих затражило да на једној страници омиљеног романа или кратке приче пронађу и заокруже деривационе афиксе, што у пракси изгледа овако: ${ }^{6}$

'Of course I know her. On the first night I was at the theatre, the horrid old Jew came round to the box after the performance was over, and offered to take me behind the scenes and introduce me to her. I was furous with him, and told him that Juliet had been dead for hundreds of years, and that her body was lying in a marble tomb in Verona. I think, from his blank look of amazent that he was under the impres 100 that I had taken too much champagne, or something.'

Приручник Гернса и Редмана (Gairns \& Redman, 1986), намењен наставницима и ученицима које интересује вокабулар, нуди кратко образложење о три најучесталија процеса творбе речи у енглеском језику (слагање, деривација и конверзија), али и појашњење педагошких импликација које из тога произлазе. Ово је праћено конкретним задацима (в. Слику 1), који се могу применити у настави, а тичу се погађања значења суфиксалних деривата, те комбиновања префикса и творбених основа.

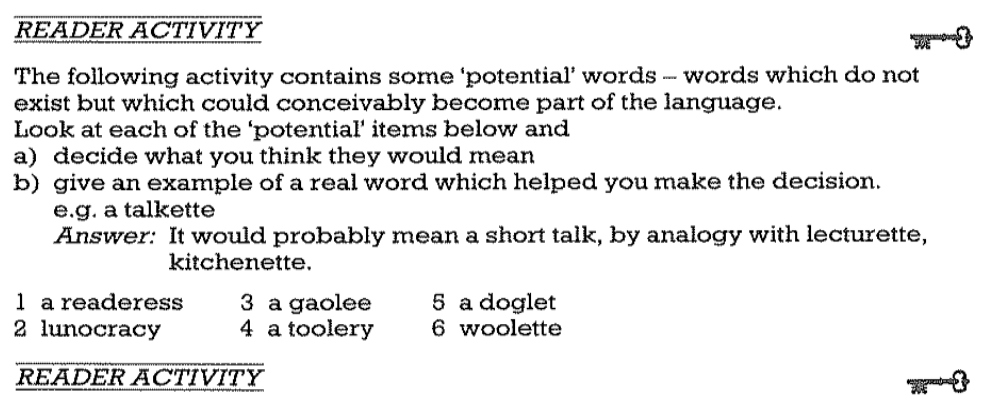

Which of the following prefixes would you be able to use with the words on the right? What meaning can you assign to each of the prefixes?

$\left.\begin{array}{|cc|}\hline \text { pret } & \text { sub }+ \\
\text { ultrat } & \text { ext }\end{array}\right] \quad$\begin{tabular}{ll|}
$\begin{array}{l}\text { wax } \\
\text { modern } \\
\text { revolutionary }\end{array}$ & $\begin{array}{l}\text { Conservative } \\
\text { human }\end{array}$ \\
\hline
\end{tabular}

Слика 1. Активности које се тичу дериващије (Гернс и Редман, 1986, стр. 47)

\footnotetext{
${ }^{6}$ Поменути одломак је из романа The picture of Dorian Gray одабрала и анализирала једна студенткиња Филолошко-уметничког факултета у Крагујевцу за потребе домаћег задатка из предмета Морфологија енглеског језика (током академске 2016/2017).
} 
О значају употребе префикса, корена и суфикса у институционалном контексту усвајања J2 највише је говорио Пол Нејшн (Nation,1990, 2001). Он је овај вид језичког знања сврстао у једну од стратегија учења које ученицима могу да олакшају разумевање нискофреквентних речи, да им омогуће да те нове речи повежу са познатим речима или афиксима, као и да лакше упамте њихово значење. Како он наводи, на часу наставник може ученицима понудити речи које треба поделити на саставне делове (нпр. pro/duct/ion или un/com/plic/ate/d). Даље, могу се попуњавати табеле које садрже чланове породице речи, као, на пример:

$$
\begin{aligned}
& \text { именица глагол придев прилог } \\
& \text { argument }
\end{aligned}
$$

Ученицима се, такође, могу давати и реченице које садрже празнине и творбену основу од које треба извести прикладан облик, попут:

I went to the doctor for a (consult).

На усвајању значења афикса и корена може се радити и тако што ученици направе картице на којима се са једне стране налази одређени афикс, а са друге његово значење, нпр.

\begin{tabular}{|l|l|}
\hline SUB- & under, below, beneath \\
\hline
\end{tabular}

Те картице ученици носе са собом док не науче сва значења, а могу се са њима на часу организовати и разне игре у пару или групи, које служе обнављању градива или провери знања. У време савремених технологија, слична активност може се организовати и помоћу интернета, тј. сајта Quizlet (https://quizlet.com/create-set) тако што наставник припреми скуп картица којима ђаци могу приступити у слободно време или на часу. Поменути сајт нуди и могућност организо-

\footnotetext{
${ }^{7}$ Чланови породице речи појављују се у тестовима Cambridge Michigan Language Assessments, нпр.:

If you find any information about the problem, please contact us immediately.

a. relating

b. related

c. relation

d. relative
}

(Преузето са сајта http://www.cambridgemichigan.org/wp-content/uploads/2014/11/ ECCE-SampleB-TestBooklet.pdf; приступљено 21. 1. 2017. године.) 
вања тестирања, па ђаци могу самостално или у пару/групи да се такмиче у познавању деривационих афикса и њихових значења. Ево како изгледа веб-страница коју је неко осмислио под насловом Derivational Affixes и какве све могућности пружа (картице, писање, тестирање, упаривање итд.):

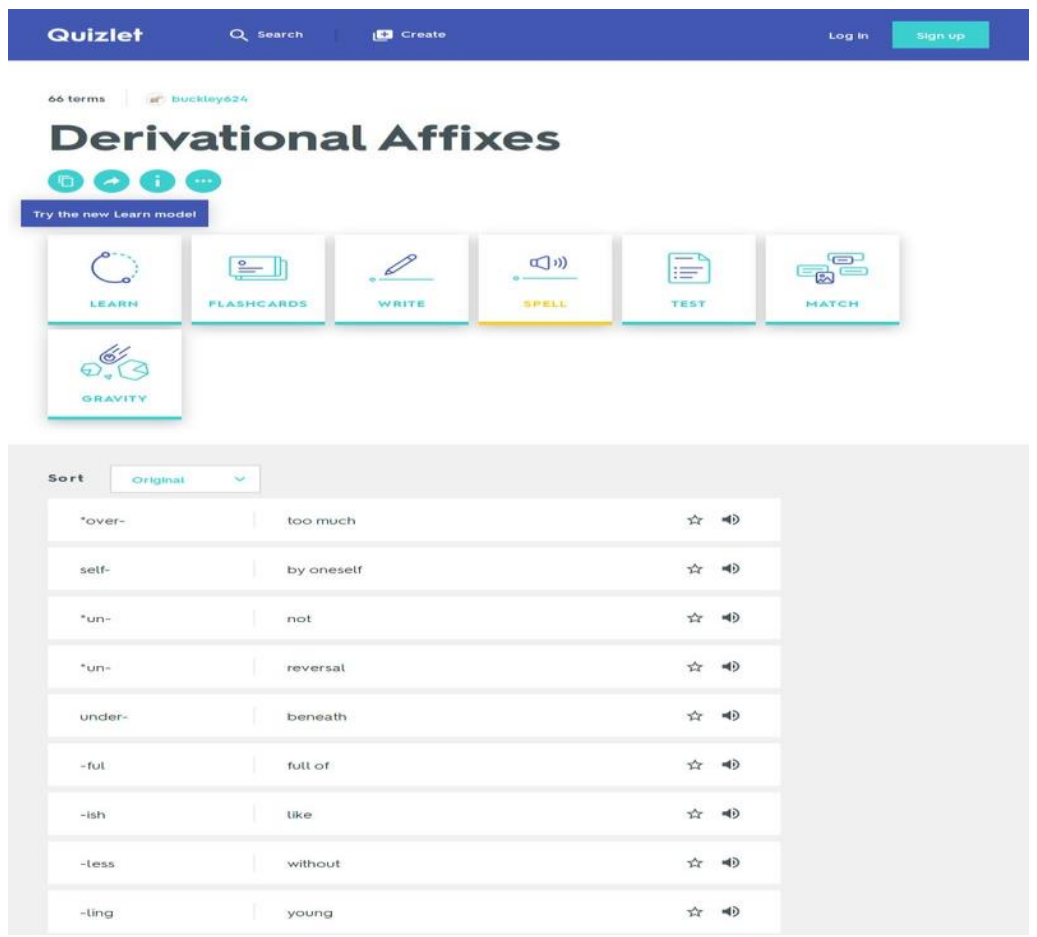

Слика 2. Могућности које веб-сајт Quizlet нуди за израду и учење помоћу картища

Напослетку, наставник може и да образложи, користећи примере или илустрације, начин на који се граде деривати у енглеском или да покаже ученицима како значења афикса доприносе значењу сложених речи; ученици, потом, могу сами да покушају да опишу шта извесне речи, које до тада нису видели или чули, значе. Аутентични примери употребе енглеског језика могу се, у данашње време, преузети из доступних електронских корпуса, као што су British $\mathrm{Na}$ tional Corpus (https://corpus.byu.edu/bnc/) или Corpus of Contemporary American English (https://corpus.byu.edu/coca/). Даље, од ученика се може тражити да у корпусу претраже одређене врсте речи које почињу циљним афиксом - примера ради, све глаголе који почињу са $d i s-$, и да затим изведу закључак о значењу и фреквентности употребе поменутог префикса. 
Морфологија се и пре процвата студија у области вокабулара деведесетих година 20. века појављивала као саставни део наставних материјала осмишљених за потребе подучавања или самосталног рада ученика енглеског као J2. Још давне 1960. године Пит Кордер издао је An intermediate practice book, вежбанку која поред граматичких објашњења и задатака, као засебан сегмент, обухвата и творбу речи. Бројна објашњења употребе префикса и суфикса, груписаних у оквиру врста речи и значења, праћена су углавном деконтекстуализованим вежбањима, попут овога:

\section{Exercise No 205. The Prefixes 'mis-' and 'dis-'}

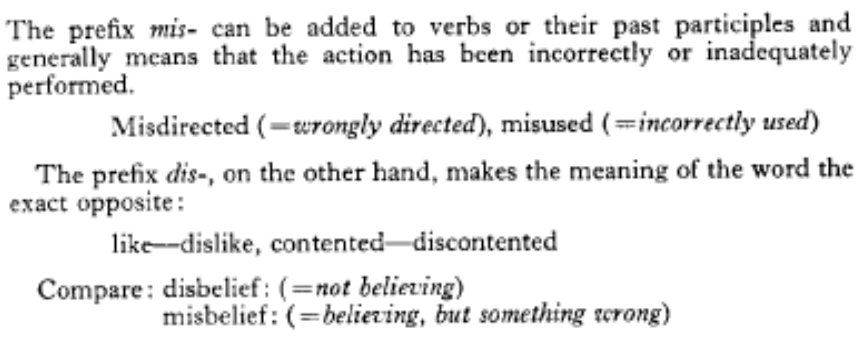

Form adjectives by adding the prefixes mis- or dis- to these past participles. Some can take both prefixes:

$\begin{array}{llll}\text { taken } & \text { informed } & \text { applied } & \text { trusted } \\ \text { judged } & \text { continued } & \text { laid } & \text { read } \\ \text { inclined } & \text { affected } & \text { placed } & \text { shapen } \\ \text { translated } & \text { used } & \text { counted } & \text { led } \\ \text { liked } & \text { spelled } & \text { understood } & \text { covered } \\ \text { ordered } & \text { pleased } & \text { appropriated } & \text { inherited } \\ \text { directed } & \text { construed } & \text { leading } & \end{array}$

Слика 3. Деконтекстуализовани задатак који захтева да се од речи изведу деривати додавањем префикса тіs- или dis-

(Corder, 1960, cmp. 191)

И Грејверов (Graver, 1986) Advanced English Practice, чије је прво издање штампано 1963. године, поред граматичких, нуди и лексичка вежбања, у оквиру којих је пажња засебно посвећена појединим придевским и глаголским афиксима, сложеницама, префиксима/суфиксима и творби речи уопште, у деконтекстуализованим задацима какве смо видели код Кордера (1960), али и контекстуализованим примерима налик овоме: 
252 Replace the words in italics by a single adjective ending in -ous, -ious, -uous, or -eous, making any necessary changes in word order.

1 Comedians must depend to some extent on the fact that laughter is likely to spread to or infuence others.

2 They chose the village hall for the party as it was roomy and had, at the same time, a homely atmosphere.

3 The audience at the circus broke into natural and unforced applause as the acrobat completed his most daring turn.

4 Trees that shed their leaves each year look very bare in winter.

5 In some of his experiments with dogs, Pavlov had to keep them from food until they were almost fierce from lack of food in order to induce the desired response to stimuli.

6 Contrary to expectations, the House was far from being all of the same mind on the question of building new universities.

7 Comparatively few people are able to use either hand with equal facility.

8 Until the nineteenth century, governments tended to view the problem of the aged and the poor with hard and insensitive indifference.

9 Shop assistants must sometimes find it difficult to remain polite and shoming good manners when faced with an unpleasant or rude customer.

10 Airline pilots undergo very strict and severe health checks at regular intervals.

Слика 4. Контекстуализовани задатак који захтева извођење придева наставком -ous, -ious, -іои или -еous

(Graver, 1986, cmp. 234)

Поред уџбеника и приручника, творба речи почела је да се појављује и у тестовима различитих, виших нивоа знања енглеског као J2, које је организовало ненаставно, непрофитно одељење Универзитета у Кембриџу, под називом University of Cambridge Local Examinations Syndicate (UCLES), касније преименованом у Cambridge English for Speakers of Other Language (ESOL) и Cambridge English Language Assessment. Њихови тестови First Certificate in English (FCE), Certificate in Advanced English (CAE) и Certificate of Proficiency in English (CРЕ) по правилу садрже краћи текст са празнинама које треба попунити одговарајућим облицима речи изведеним на основу понуђених мотиватора, што изгледа овако: 


\section{Part 5}

For questions 56-65, read the text below. Use the word gyen in caotals at the end of each ine to form a word that fits in the spoce in the same line. There is an exarple at the begrning $(0)$. Write your answers on the separate answer sheet.

Example: \begin{tabular}{|l|l|}
\hline 0 & ability \\
\hline
\end{tabular}

\section{COMPUTERS THAT PLAY GAMES}

Compuvers have had the $\langle 0\rangle$..........ty..., to ploy chess for manry years now, and their (56) . in games aginst the best players in

the world has shown steady (57) Howevec it will be yoars before designers of oomputer gares machines can beat their (58) .............. chalenge yet - the anoient board gane caled Go. The playing eree is (59) _............ langer than in chess and there are fer more peces, so that the $(60)$.............. of moves is almost (61) mun.... The game invates plannire so many moves ahead that even the (62) isw........ calculations of the fastest modern computers are (63) ............. to deal with the probiems of the game. ABLE PERFORM IMPROVE

\section{BIG} CONSIDERABLE COMBINE

END IMPRESS In rocent (64) …m.n. for computer Go machines, the best COMPCTE machine beat all its computer reals, but lost (65) ............. to thee HEAVY younk schoolchildren, 90 there is obvicusty still a lot of work to dol

Слика 5. Творба речи у кембричком тесту FCE (Hughes, 2003, стр. 176)

Појављивање сегмента творбе речи у горепоменутим тестовима, у оквиру одељка Use of English (срп. употреба енглеског), допринело је осмишљавању бројних сличних задатака који су уврштени у приручнике и уџбенике за припрему ових испита. Фаулеров (Fowler, 1996) First Certificate: Use of English тако нуди детаљна појашњења задатака који ученике чекају на испиту, као и основне информације о начинима на које се граде именице, глаголи, придеви и прилози у енглеском, праћене примерима који илуструју њихово значење и употребу. Свако образложење прате бројне реченице са празнинама које пружају ученицима могућност да унапреде своје познавање морфологије, изводећи примерене облике од понуђених творбених основа. На крају књиге, понуђено је и неколико тестова који по форми одговарају задатку са кембричких испита, а служе учвршћивању и провери знања.

Слична је ситуација и са уџбеницима страних издавача (нпр. Longman, Oxford University Press или Cambridge University Press) за нивое Б2, Ц1 и Ц2 (према Заједничком европском оквиру за живе је- 
зике), који заправо одговарају горенаведеним кембричким тестовима вишег нивоа знања језика. Вежбе творбе речи у њима се појављују у оквиру наставних јединица (енгл. unit) и обично тематски прате главне текстове који су обрађени, а објашњења у вези са творбеним процесима варирају од непостојећих или штурих, па до веома темељних, у зависности од уџбеника.

Мора се, међутим, признати да има и уџбеника у којима не само да нема (де)контекстуализованих вежбања творбе речи него се поменути процес у њима уопште не спомиње, као што је случај са Focus on First Certificate (O’Connell, 1996).

На крају, вредно је помена да домаћи уџбеници не занемарују улогу морфолошког аспекта у усвајању енглеског као J2, о чему сведочи магистарски рад Слободана Јовановића (2005), у оквиру кога су анализирани како основношколски тако и средњошколски уџбеници (првенствено намењени настави енглеског у гимназијама). Аутор запажа да се на нижим нивоима усвајања енглеског језика пажња на морфолошке процесе усмерава ненаметљиво, без експлицитно изложене терминологије или теоретских формулација, у виду кратких и лако уочљивих приказа. У вишим разредима средње школе јављају ce, у издвојеним одељцима под називом Word formation (срп. творба речи), и објашњења посвећена значењу и употреби афикса, уз пратећа вежбања (уп. Грба, 2003, стр. 197).

\section{ЗАКЉУЧАК}

Комуникативни метод скренуо је пажњу на значај различитих компетенција за успешно комуницирање на другом/страном језику. У једну од тих компетенција убраја се и граматичка, у чијем саставу су се нашли и лексичка, као и морфолошка компонента језичког знања. Бројни истраживачи сагласни су да морфологија заслужује више простора у настави, јер развијена свест о морфолошким процесима, као једна од језичких стратегија, доприноси не само унапређеној језичкој рецепцији већ и продукцији.

Будући да лексички фонд енглеског језика чине бројне нискофреквентне речи латинског и грчког порекла, које садрже префиксе или суфиксе, а неретко и оба, способност рашчлањивања сложених речи на саставне делове и уочавања аналогија у формирању деривата може да олакша разумевање речи и њихово памћење. Штавише, познавање афикса и чланова породица речи може омогућити ученицима да сами произведу деривационе форме.

Значај свести о морфолошким сегментима видљив је и у тестовима појединих институција, али и у наставним материјалима за учење енглеског језика. Познавање деривације проверава се на кембричким испитима вишег нивоа знања, на којима кандидати морају да покажу да су постигли одређени ниво језичких способности. 
Морфологија је нашла своје место и у уџбеницима и приручницима за наставу енглеског као J2; у њима се махом појављују неопширна образложења значења и употребе афикса, праћена (де)контекстуализованим задацима. Постоје, ипак, и бројни други начини да се афикси обрађују на часу, попут игара или различитих активности које подстичу ученике да у пару или групи раде на откривању и сврставању карактеристика деривата и њиховом учењу. У доба рачунара и мобилних телефона, наставницима се пружају нове могућности подучавања лексике и морфологије које подстичу ученике да самостално раде на обогаћивању свог лексичког фонда, што би могло да унапреди и олакша наставни процес.

\section{ЛИТЕРАТУРА}

Adams, V. (2013). Complex words in English. New York: Routledge,

Bauer, L. (1983). English Word-Formation. Cambridge: Cambridge University Press.

Barnard, H. (1961). A test of P.U.C. students' vocabulary in Chotanagpur. Bulletin of the Central Institute of English, 1, 90-100.

Bird, N. (1987). Words, lemmas, and frequency lists: old problems and new challenges. Almanakh, 6, 42-50.

Channell, J. (1988). Psycholinguistic considerations in the study of L2 vocabulary acquisition. In R. Carter, M. McCarthy (Eds.), Vocabulary and Language Teaching (pp. 83-96). London: Longman.

Corder, S.P. (1960). An Intermediate English Practice Book. Harlow: Longman.

Corson, D.J. (1985). The Lexical Bar. Oxford: Pergamon.

Corson, D.J. (1995). Using English Words. Dordrecht: Kluwer.

Corson, D.J. (1997). The learning and use of academic English words. Language Learning, 47(4), 671-718.

Coxhead, A. (1998). An Academic Word List. Wellington, NZ: Victoria University of Wellington.

Coxhead, A. (2000). A new academic word list. TESOL Quarterly, 34(2), 213-238.

Craik, F. \& Lockhart, R. (1972). Levels of processing: a framework for memory research. Journal of Verbal Learning and Verbal Behavior, 11, 671-684.

Danilović, J., Dimitrijević Savić, J. \& Dimitrijević, M. (2013). Affix acquisition order in Serbian EFL learners. Romanian Journal of English Studies, 10, 77-88.

Dimitrijević Savić, J. \& Danilović, J. (2011). Cognate suffixes: (false) friends to the acquisition of productive knowledge of English derivational morphology in Serbian EFL learners. In N. Tomović, J. Vujić (Eds.), English language and literature studies: image, identity, reality (pp. 427-436). Belgrade: Čigoja štampa.

Fowler, W.S. (1996). First Certificate: Use of English. Harlow: Longman.

Gairns, R. \& Redman, S. (1986). Working with words: A guide to teaching and learning vocabulary. Cambridge: Cambridge University Press.

Graver, B.D. (1986). Advanced English practice. Oxford: Oxford University Press.

Grba, G. (2003). Engleski jezik za treći razred gimnazije [English for the third year of grammar school]. Beograd: Zavod za udžbenike i nastavna sredstva.

Harley, H. (2006). English Words: A Linguistic Introduction. Malden, MA: Blackwell Publishing.

Hughes, A. (2003). Testing for Language Teachers. Cambridge: Cambridge University Press. 
Jovanović, S. (2005). Oblast tvorbe reči u osnovnoškolskim i srednjoškolskim udžbenicima engleskog jezika (magistarski rad) [Word-formation in English coursebooks for primary and secondary levels of education, MA thesis]. Beograd: Filološki fakultet.

Kucera, H. \& Francis, W.N. (1967). A Computational Analysis of Present-Day American English. Providence, RI: Brown University Press.

Laufer, B. (1997). What's in a word that makes it hard or easy: some intralexical factors that affect the learning of words. In N. Schmitt, M. McCarthy (Eds.), Vocabulary: Description, Acquisition and Pedagogy (pp. 140-155). Cambridge: Cambridge University Press.

Milton, J. \& Meara, P.M. (1995). How periods abroad affect vocabulary growth in a foreign language. ITL, 107-108, 17-34.

Morgan, J. \& Rinvolucri, M. (2004). Vocabulary. Oxford: Oxford University Press.

Nagy, W.E. \& Anderson, R.C. (1984). How many words are there in printed school English? Reading Research Quarterly, 20, 233-253.

Nagy, W.E., Diakidoy, I.N. \& Anderson, R.C. (1993). The acquisition of morphology: Learning the contribution of suffixes to the meaning of derivatives. Journal of Reading Behavior, 25, 155-170.

Nation, P. (1990). Teaching and Learning Vocabulary. Massachusetts: Newbury House.

Nation, P. (Ed.) (1994). New ways in teaching vocabulary. Alexandria: TESOL.

Nation, P. \& Waring, R. (1997). Vocabulary size, text coverage and word lists. In N. Schmitt \& M. McCarthy (Eds.), Vocabulary: Description, Acquisition and Pedagogy (pp. 6-19). Cambridge: Cambridge University Press.

Nation, P. (2001). Learning Vocabulary in Another Language. Cambridge: Cambridge University Press.

O’Dell, F. (1997). Incorporating vocabulary into the syllabus. In N. Schmitt \& M. McCarthy (Eds.), Vocabulary: Description, Acquisition and Pedagogy (pp. 258-278). Cambridge: Cambridge University Press.

O'Connell, S. (1996). Focus on First Certificate. Harlow: Longman.

Olmos, C. (2009). An assessment of the vocabulary knowledge of students in the final year of secondary education. Is their vocabulary extensive enough? International Journal of English Studies, special issue, 73-90.

Otwinowska-Kasztelanic, A. (2010). Language awareness in using cognate vocabulary: the case of Polish advanced students in the light of the theory of affordance. In J. Arabski, A. Woitaszek (Eds.), Neurolinguistic and Psycholinguistic Perspectives on SLA (pp. 175-190). Clevedon: Multilingual Matters.

Oxford, R.L. (1990). A new taxonomy for second language learning strategies. New York: Newbury House.

Plag, I. (2003). Word-formation in English. Cambridge: Cambridge University Press.

Pyles, T. \& Algeo, J. (1993). The Origins and Development of the English Language. Boston, MA: Heinle.

Quinn, G. (1968). The English Vocabulary of Some Indonesian University Entrants. Salatiga: English Department Monograph IKIP Kristen Satya Watjana.

Read, J. (2000). Assessing Vocabulary. Cambridge: Cambridge University Press.

Richards, J. \& Rodgers, T. (2001). Approaches and Methods in Language Teaching. Cambridge: Cambridge University Press.

Schmitt, N. (1997). Vocabulary learning strategies. In N. Schmitt \& M. McCarthy (Eds.), Vocabulary: Description, Acquisition and Pedagogy (pp. 199-227). Cambridge: Cambridge University Press.

Schmitt, N. (2000). Vocabulary in language teaching. Cambridge: Cambridge University Press. 
Schmitt, N. \& McCarthy, M. (Eds.) (1997). Vocabulary: Description, Acquisition and Pedagogy. Cambridge: Cambridge University Press.

Singleton, D. (1989). Language acquisition: the age factor. Clevedon: Multilingual Matters.

Thorndike, E.L. \& Lorge, I. (1944). The Teacher's Word Book of 30,000 Words. New York: Columbia University, Teachers College.

West, M. (1953). A General Service List of English Words, with Semantic Frequencies and a Supplementary Word-list for the Writing of Popular Science and Technology. London: Longmans, Green.

\title{
TEACHING ENGLISH VOCABULARY: THE ROLE OF DERIVATION
}

\author{
Jelena Danilović Jeremić \\ University of Kragujevac, Faculty of Philology and Arts, Kragujevac, Serbia
}

\begin{abstract}
Summary
Derivation represents one of the three key morphological processes, besides composition and conversion, that contribute to the lexical expansion of the contemporary English language. Owing to a variety of historical and social factors, the English derivational system is characterized by a mixture of native and foreign bases and affixes, all of which play a part in the formation of new words. Morphological and psycholinguistic research has suggested that it is precisely due to their implicit morphological knowledge, i.e. the knowledge of word structure and derivational affixes, that native speakers of English are not only able to understand lexemes which they have never encountered before but can readily create new lexical items independently. We can, therefore, conclude that morphological knowledge constitutes an essential element of an individual's lexical knowledge. Unlike native speakers, whose lexical growth occurs spontaneously and rapidly, non-native speakers' acquisition of lexis, in a formal EFL teaching context, is typically a painstaking and enduring process, often an unsuccessful one. For this very reason, the aim of this paper is to emphasize the importance of derivation in teaching English vocabulary. This will be achieved, first, by a detailed description of the structure of English words and the size of the learners' vocabulary. Secondly, the connection will be established between morphological structure of words and different aspects of word knowledge, within the three-tier framework of form, structure and meaning. Moreover, given that $\mathrm{L} 1$ can facilitate the acquisition of a foreign language, the paper will shed light on the pedagogical potential of a growing body of English-Serbian pairs of cognate lexemes. Finally, and in order to enable English teachers to foster the development of lexical knowledge in their learners by implementing various strategies, we will provide an overview of learning activities and games which have found their way into EFL textbooks and handbooks as well as test formats of certain relevant institutions (e.g. Cambridge English Language Assessment, Cambridge Michigan Language Assessment). In conclusion, we will stress that introducing learners to the characteristic features of derivational affixes can not only broaden their lexical knowledge, both reception- and production-wise, but also promote the development of learner autonomy, which is equally important.
\end{abstract}

